\title{
THE OCCURRENCE OF PORPHYRINS IN CERTAIN MARINE INVERTEBRATES
}

\author{
By G. Y. Kennedy \\ Department of Cancer Research, University of Sheffield \\ and H. G. Vevers \\ The Plymouth Laboratory
}

(Text-fig. I)

Kennedy \& Vevers $(1953 a, b)$ confirmed the presence of a porphyrin in the integument of the starfish Asterias rubens, reported by MacMunn (1887), and showed that it was protoporphyrin. A yield of $33.6 \mathrm{mg}$ of protoporphyrin dimethyl ester was obtained from $548.5 \mathrm{~g}$ of Asterias integument. Following this work, and the investigation of porphyrins in mollusc shells by Nicholas \& Comfort (1949), it was naturally of interest to examine the distribution of porphyrin pigments in the soft and skeletal parts of other marine animals. A survey has therefore been made of the occurrence of porphyrins in certain invertebrates common in the waters off Plymouth.

\section{Methods}

The animals were examined first in the fresh state under ultra-violet light (Osira I25 W black glass lamp) and then homogenised (in an Atomix blender) and extracted by the methods used previously (Kennedy \& Vevers, $1953 b$ ). The extracts in turn were examined by ultra-violet light and the occurrence of red fluorescence noted. Where extracts showed red fluorescence the source of this was investigated chemically and, where possible, the pigments responsible for this fluorescence were isolated and characterized by the following methods:

(I) Solubility in ether, chloroform, ethyl acetate, O.IN hydrochloric acid, and O.IN sodium hydroxide.

(2) Partition between ether and increasing concentrations of aqueous hydrochloric acid from $0 . \mathrm{I} \%(\mathrm{w} / \mathrm{v})$, this is the $\mathrm{HCl}$ number (Salzsäurezahl) of Willstätter \& Stoll (I913).

(3) Column chromatography, Nicholas (I95I) and Kennedy (I953a).

(4) Paper partition chromatography Nicholas \& Rimington (1949), Kennedy $(\mathrm{I} 953 b)$ and $\mathrm{Chu}, \mathrm{Green} \& \mathrm{Chu}(\mathrm{I} 95 \mathrm{I})$.

(5) Absorption spectra, using a Beck-Hartridge Reversion spectroscope, and a Unicam S.P. 500 spectrophotometer.

(6) Formation of derivatives and conversion to other porphyrins, when sufficiennt material was available. 


\section{TABle I. OCCURRENCE OF Red FluORESCENCE IN Extracts FROM CERTAIN MARINE INVERTEBRATES}

(Extracts of whole animal except where otherwise stated.)

\begin{tabular}{|c|c|c|c|}
\hline \multirow[b]{3}{*}{ PORIFERA } & \multicolumn{2}{|c|}{ Red fluorescence due to } & \multirow{3}{*}{ Remarks } \\
\hline & Porphyrins & $\begin{array}{c}\text { Chlorophyll } \\
\text { and } \\
\text { derivatives }\end{array}$ & \\
\hline & - & - & \\
\hline Grantia compressa & - & $\overline{-}$ & $\dot{.}$ \\
\hline Tethya aurantium & $?+$ & - & $\begin{array}{l}\text { Not yet } \\
\text { identified }\end{array}$ \\
\hline Halichondria panicea & - & + & Algae \\
\hline $\begin{array}{l}\text { COELENTERATA } \\
\text { Velella spirans (skeleton) }\end{array}$ & & & \\
\hline $\begin{array}{l}\text { Velella spirans (skeleton) } \\
\text { V. spirans (soft parts) }\end{array}$ & - & - & $\cdot$ \\
\hline $\begin{array}{l}V . \text { spirans (soft parts) } \\
\text { Alcyonium digitatum }\end{array}$ & $\overline{-}$ & $\overline{-}$ & $\cdot$ \\
\hline $\begin{array}{l}\text { Alcyonium digitatum } \\
\text { Actinia equina }\end{array}$ & - & $\begin{array}{l}- \\
-\end{array}$ & $\dot{.}$ \\
\hline Anemonia sulcata & - & + & Algal symbionts \\
\hline Tealia felina & - & - & . \\
\hline Metridium senile & - & - & . \\
\hline Calliactis parasitica & - & - & . \\
\hline $\begin{array}{l}\text { ANNELIDA } \\
\text { Aphrodite aculeata }\end{array}$ & & & \\
\hline $\begin{array}{l}\text { Aphrodite aculeata } \\
\text { Nereis diversicolor }\end{array}$ & $\overline{+}$ & $\overline{+}(a)$ & $\cdot$ \\
\hline $\begin{array}{l}\text { Nereis diversicolor } \\
\text { Perinereis cultrifera }\end{array}$ & - & $\pm(a)$ & : \\
\hline Chaetopterus variopedatus & + & $+(b)$ & $\dot{.}$ \\
\hline Arenicola marina & - & - & $\dot{.}$ \\
\hline Myxicola infundibulum & - & - & $\dot{.}$ \\
\hline M. infundibulum (purple tentacles) & - & - & $\dot{.}$ \\
\hline M. infundibulum (alimentary system) & + & - & . \\
\hline ARTHROPODA & & & \\
\hline Portunus depurator & - & - & \\
\hline Carcinides moenas (soft parts) & - & + & $\begin{array}{l}\text { From diet in } \\
\text { alimentary } \\
\text { tract }\end{array}$ \\
\hline C. moenas (carapace) & - & - & . \\
\hline Cancer pagurus (eggs) & - & - & . \\
\hline C. pagurus (viscera) & - & - & - \\
\hline C. pagurus (claw shell) & - & - & - \\
\hline C. pagurus (carapace) & - & - & $\cdot$ \\
\hline Eupagurus bernhardus (soft parts) & - & - & $\cdot$ \\
\hline MOLLUSCA & - & - & \\
\hline $\begin{array}{l}\text { Mytilus edulis } \\
\text { M. edulis (shell) }\end{array}$ & - & - & : \\
\hline $\begin{array}{l}\text { M. edults (shell) } \\
\text { Chlamys opercularis }\end{array}$ & - & - & : \\
\hline C. opercularis (mantle) & - & - & $\dot{.}$ \\
\hline Cardium edule (soft parts) & - & - & $\dot{.}$ \\
\hline Buccinum undatum (soft parts) & - & - & $\dot{.}$ \\
\hline Scaphander lignarius (bursae) & - & - & . \\
\hline Philine aperta (bursae) & - & - & . \\
\hline Aplysia punctata (integument) & + & - & . \\
\hline forunna tomentosa & - & - & $\cdot$ \\
\hline Archidoris britannica & - & $\bar{t}$ & \\
\hline A. britannica (eggs) & - & & $\begin{array}{l}\text { Chlorophyll } \\
\text { from Algae }\end{array}$ \\
\hline $\begin{array}{l}\text { Duvaucelia plebeia (upper integument) } \\
\text { Loligo forbesi }\end{array}$ & \pm & $\overline{-}$ & $\cdot$ \\
\hline $\begin{array}{l}\text { Loligo forbesi } \\
\text { Parasepia elegans }\end{array}$ & - & - & $\dot{.}$ \\
\hline
\end{tabular}




\section{TABLE I (continued)}

\section{ECHINODERMATA \\ Antedon bifida \\ Astropecten irregularis (integument) \\ Luidia ciliaris (integument) \\ Porania pulvillus (integument) \\ Palmipes membranaceus (integument) \\ Solaster papposus (integument) \\ Henricia sanguinolenta (integument) \\ Asterias rubens (integument) \\ Marthasterias glacialis (integument) \\ M. glacialis (spicules) \\ Ophiothrix fragilis \\ Ophiocomina nigra \\ Psammechinus miliaris (test)}

Holothuria forskali (integument)

Tunicata

Ascidiella aspersa (viscera)

Ciona intestinalis (viscera)

(a) Phaeophorbide $a$; (b) Phaeophorbides $a$ and $b$.

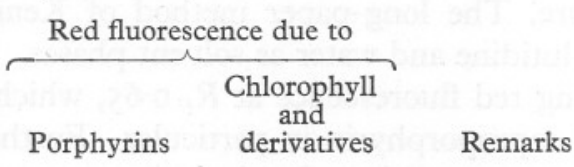

The results of this survey are given in Table I, and further details of those animals in which porphyrins were found are given in Table II. Where positive identification of pigments was possible the evidence upon which this was based is described under the name of the pigment.

\section{Table II. OCcurrence of Porphyrins in Certain Marine InVertebrates}

\begin{tabular}{|c|c|c|c|}
\hline Phylum & Species & Porphyrin & Distribution \\
\hline \multirow[t]{3}{*}{ Annelida } & Nereis diversicolor & Coproporphyrin III & Viscera \\
\hline & Chaetopterus variopedatus & $\begin{array}{l}\text { Coproporphyrin III and } \\
\text { a pentacarboxylic } \\
\text { porphyrin }\end{array}$ & Viscera \\
\hline & Myxicola infundibulum & Coproporphyrin III & Viscera \\
\hline \multirow[t]{2}{*}{ Mollusca } & Aplysia punctata & Uroporphyrin I & Integument \\
\hline & Duvaucelia plebeia & Uroporphyrin I & Integument \\
\hline \multirow[t]{4}{*}{ Echinodermata } & Astropecten irregularis & Chlorocruoroporphyrin & Integument \\
\hline & Luidia ciliaris & $\begin{array}{l}\text { and protoporphyrin } \\
\text { Chlorocruoroporphyrin }\end{array}$ & Integument \\
\hline & as rubens & and protoporphyrin & \\
\hline & as rubens & Protoporphyrin & Integument \\
\hline
\end{tabular}

\section{IDENTIFICATION OF PigMENTS}

Coproporphyrin III

This pigment was noticed during the course of paper partition chromatography (Nicholas \& Rimington, 1949) of chloroform extracts of the three polychaetes-Nereis, Chaetopterus and Myxicola - in an investigation of the 
green pigment 'chaetopterin' (with J. A. C. Nicol), to be reported in the near future. The long-paper method of Kennedy (1953 $b$ ) was employed, with 2:6-lutidine and water as solvent phases. A well defined spot appeared, with strong red fluorescence at $R_{F} 0.65$, which suggested a 4-COOH porphyrin, and coproporphyrin in particular. Further chromatograms were run under the same conditions, but including on each paper a spot of coproporphyrin I as a marker, in both adjacent and mixed spots. Only one spot appeared at $R_{F} 0.65$ on the mixed spot papers, and on the papers with adjacent spots there were two spots side by side at $R_{F} 0 \cdot 65$. This confirmed the presence of a $4-\mathrm{COOH}$ porphyrin, and strongly suggested coproporphyrin.

There was very little material for experiment so the spots of all the longpaper chromatography experiments were cut out carefully, the pieces soaked in a little dry pyridine and examined spectrophotometrically. The spectrum showed the maxima:

$\begin{array}{cccc}\text { I } & \text { II } & \text { III } & \text { IV } \\ 623.6 & 569 \cdot 0 & 533^{\circ} \circ & 499 \cdot 0 \mathrm{~m} \mu\end{array}$

further indicating that this porphyrin is indeed a coproporphyrin.

Concentrated solutions of the extracts from the three worms were then evaporated to dryness in vacuo, the residues esterified with methanol/hydrochloric acid and examined by the double-development paper-chromatography method of Chu et al. (I95I), using chloroform: kerosene/ $n$-propanol:kerosene at $19^{\circ} \mathrm{C}$. Well-marked spots were observed with centre-dense red fluorescence at $R_{F} 0.8 \mathrm{I}$, corresponding to coproporphyrin III. The test was repeated with markers of coproporphyrin I tetramethyl ester and coproporphyrin III tetramethyl ester (the latter very kindly supplied by Prof. C. Rimington, F.R.S.) in both adjacent and mixed spots. On those papers bearing the extracts and coproporphyrin I in mixed spots, two clear sets of spots were seen, indicating that the two porphyrins were not identical. On those papers bearing adjacent spots of coproporphyrin I and extract, there was a wide difference between the $R_{F}$ values.

Papers carrying mixed spots of the worm extracts with authentic coproporphyrin III showed only one set of spots at $R_{F} 0.80$ confirming that the worm porphyrin was, in fact, identical with coproporphyrin III. Papers bearing adjacent spots of the coproporphyrin III ester and the worm extract showed that both pigments travelled together in parallel, and took up the same $R_{F}$ position, 0.80 . This established that the worm porphyrin was present as coproporphyrin III.

\section{A Penta-carboxylic Porphyrin}

In the course of these long-paper chromatography experiments just described, extracts of Chaetopterus variopedatus produced a spot above that of coproporphyrin with an $R_{F}$ value of 0.5. This is indicative of a porphyrin with five carboxyl groups. This was repeated several times and confirmed, but there 
was insufficient material for exact characterization. Further material is being collected for a detailed examination of this porphyrin.

\section{Uroporphyrin}

The upper integument of the nudibranch gastropod Duvaucelia (Tritonia) plebeia yielded no red fluorescent material to ether/acetic acid, but on placing the tissue in a mixture of absolute methanol (I9 parts) and concentrated sulphuric acid (I part) overnight the extract was found to be slightly red fluorescent to ultra-violet light. This fluorescence increased very much in intensity on diluting the extract with water, shaking up with chloroform and then examining the chloroform hypophase under ultra-violet light.

The chloroform extract was roughly dried by filtration and evaporated to dryness, and the residue was then re-dissolved in chloroform. This chloroform extract was passed through a column of alumina grade IV (Nicholas, I95I), packed by sprinkling into chloroform, and a broad red fluorescent band formed at the top of the column, with a diffuse pinkish non-fluorescent band below. The top band was immovable with ethanol/chloroform mixtures, ether, ether/ pyridine mixtures, acetone or ethyl acetate, but was eventually eluted with the methanol/sulphuric acid (I9:I) esterification mixture. The pigment was collected as a purple-red solution, intensely red fluorescent. A greyish nonfluorescent band was left on the column.

The acid/methanol solution was diluted with two-thirds of its volume of water, and the pigment was extracted with chloroform to form a purple hypophase with intense red fluorescence. The hypophase was then separated, washed several times with $2 \%$ sodium chloride, and finally with water. The solution was roughly dried by filtration through chloroform-soaked paper and evaporated to dryness on the water-bath. The pigment was redissolved in dry chloroform and the absorption spectrum determined spectrophotometrically (Unicam S.P. 500), and plotted as $E_{\mathrm{r} \mathrm{cm}}$ against wave-length. The maxima were:

$\begin{array}{ccccc}\text { I } & \text { II } & \text { III } & \text { IV } & \text { Sorêt band } \\ 624 & 572 & 535.5 & 501 & 406 \quad \mathrm{~m} \mu\end{array}$

This suggested uroporphyrin and an authentic specimen of uroporphyrin I, when examined in chloroform in the same spectrophotometer, gave maxima at:

$\begin{array}{ccccc}\text { I } & \text { II } & \text { III } & \text { IV } & \text { Sorêt band } \\ 624 & 570.5 & 535 & 50 \text { I } & 406 \quad \mathrm{~m} \mu\end{array}$

These peaks show very good agreement, as may be seen in Fig. I. A mixture of uroporphyrin I octamethyl ester and the Duvaucelia porphyrin ester were made in equal proportions as far as possible and examined in the spectrophotometer. (If two dissimilar substances are examined spectrophotometrically the peaks of the absorption curve are usually very rounded and the 
curve presents an undulating instead of a sharp appearance.) The maxima in this case were:

$\begin{array}{cccccc}\text { I } & \text { II } & \text { III } & \text { IV } & \text { Sorêt band } \\ 624 & 570.5 & 535 & 501 & 405 & \mathrm{~m} \mu\end{array}$

The peaks of the curve (Fig. I) are very sharp and the curve suggests the presence of one pure substance only.

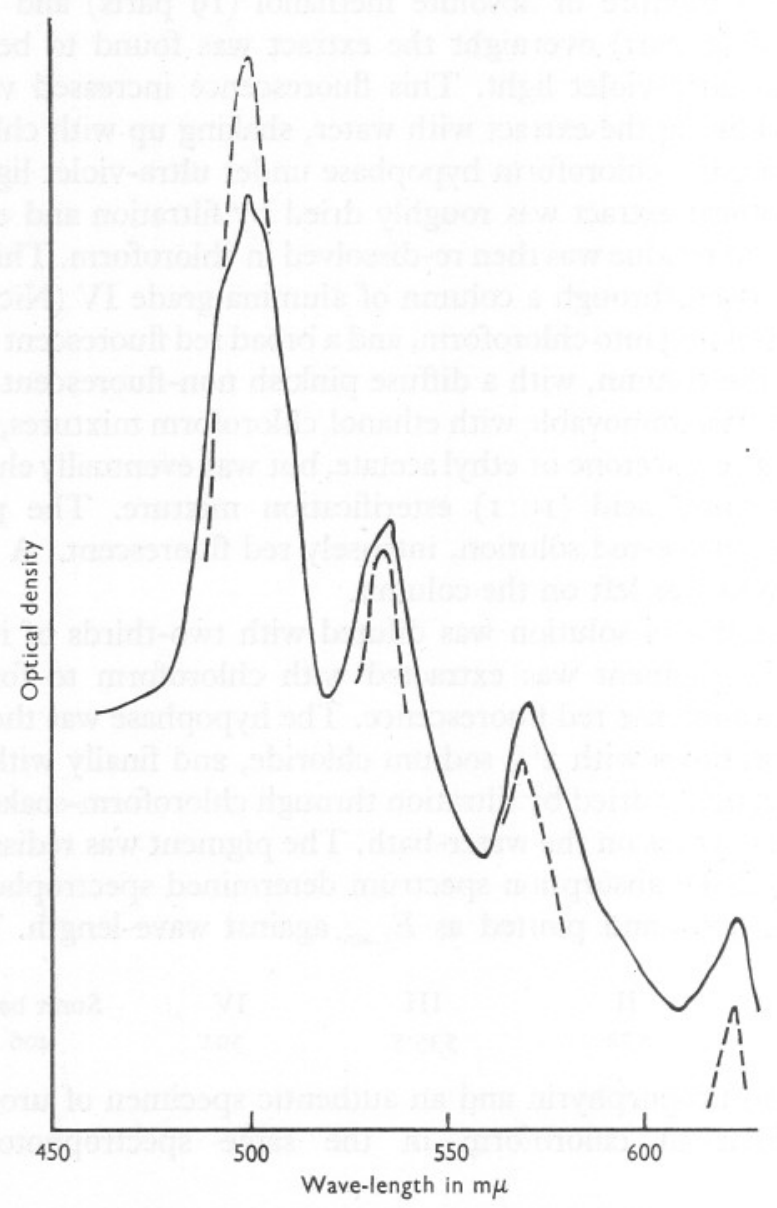

Fig. I. Absorption spectra of Duvaucelia porphyrin in chloroform. trum of Duvaucelia porphyrin alone; -...-, absorption spectrum of a mixture of Duvaucelia porphyrin and authentic uroporphyrin I.

A little of the porphyrin ester solution from Duvaucelia was evaporated to dryness and hydrolysed by dissolving it in $7 \mathrm{~N}-\mathrm{HCl}$ and standing at room temperature for $36 \mathrm{~h}$. At the end of this time the excess acid was removed by placing the dish in a vacuum desiccator over solid potassium hydroxide until 
dry. The residue was dissolved in a little chloroform, spotted on a long paper (Kennedy, $1953 \mathrm{~b}$ ) and developed at $23^{\circ} \mathrm{C}$ with $2: 6$-lutidine/water $(5: 3)$ in an atmosphere of ammonia. The resulting chromatogram showed a single spot at $R_{F}$ O.I5, indicating a porphyrin with eight carboxyl groups. This test was repeated using pure uroporphyrin I as a marker. With mixed spots only one large spot appeared at $R_{F} 0.15$ with a small spot above it at $R_{F} 0.09$ (the 'second spot' of uroporphyrin). In chromatograms with authentic uroporphyrin I as marker, parallel spots formed at $R_{F} 0.15$ and one small spot on the marker side at $R_{F} 0.09$.

These results together with the absorption spectrum confirm that the Duvaucelia porphyrin is uroporphyrin. The uroporphyrin was characterized as isomer I by the two-dimensional paper chromatogram technique of Falk \& Benson (I953), and (at Sheffield) by its decarboxylation to coproporphyrin I identified by the Chu, Green \& Chu (I95I) technique.

\section{The Porphyrin of Aplysia punctata}

The upper integument was carefully removed from fifteen Aplysia punctata, all collected from Looe by Dr B. C. Abbott, to whom we are indebted for his kindness. The material was washed in several changes of fresh water to remove as much as possible of the 'aplysiopurpurin' pigment. The integuments were then dried roughly on filter-paper and extracts made in exactly the same way as for Duvaucelia. The final chloroform extract was evaporated to dryness and redissolved in dry chloroform and chromatographed on magnesia grade III (Nicholas, I95I). The material quickly resolved itself into a series of bands as follows, from the top downwards:

(I) Greyish.

(2) Brown-purple.

(3) Green.
(4) Blue.

(5) Purple (red fluorescent).

(6) Yellow (blue fluorescent).

It proved impossible to separate bands 5 and 6 from one another, and they were collected together. The other bands, although interesting, were discarded for the present, to be investigated in the future. The red fluorescent chloroform extract containing bands 5 and 6 was evaporated to dryness, to give a fatty residue. This was redissolved in dry chloroform and the absorption curve determined in the spectrophotometer. The following maxima were obtained:

$\begin{array}{llllr}\text { I } & \text { II } & \text { III } & \text { IV } & \text { Sorêt band } \\ 624 & 570 & 534 & 50 \mathrm{I} & 406 \mathrm{~m} \mu\end{array}$

This strongly suggested uroporphyrin, an authentic specimen of which gave the maxima described under the Duvaucelia pigment.

Some of the Aplysia porphyrin ester was hydrolysed by standing in $7 \mathrm{~N}-\mathrm{HCl}$ for $48 \mathrm{~h}$ and the acid removed by standing over solid $\mathrm{KOH}$ in vacuo over- 
night. The residue was dissolved in 2:6-lutidine and examined in the longpaper chromatograph in a 2:6-lutidine/water system in an atmosphere of ammonia at $23^{\circ} \mathrm{C}$. Three papers were run, including the Aplysia porphyrin alone, and with authentic uroporphyrin $I$ as marker in mixed and adjacent spots. On all papers two spots were obtained at $R_{F} 0.09$ and 0.15 , indicating that the porphyrin of Aplysia was a uroporphyrin.

The Chu et al. (I95I) technique, followed by that of Falk \& Benson (I953) established the uroporphyrin as isomer I, confirmed (at Sheffield) by its conversion to coproporphyrin I.

\section{The Porphyrins of Luidia ciliaris}

The upper integument of the starfish $L$. ciliaris was extracted in the usual way with a methanol-sulphuric acid (I9: I) mixture and the porphyrin brought into chloroform. After evaporation to dryness on the water-bath this extract was redissolved in dry chloroform and chromatographed on magnesia grade III (Nicholas, I95I). The column was monitored by ultra-violet light. A blue fluorescent band of fatty material passed rapidly down the column and was discarded. Two purplish bands, both red fluorescent, then appeared and passed very slowly down the column about $2 \mathrm{~cm}$ apart. These were eventually eluted with chloroform-methanol (I00:3) (band I) and chloroform-methanol (I00:5) (band 2) respectively.

Band I. This was identified as protoporphyrin by spectrophotometry in pyridine (including comparison with authentic protoporphyrin) and by conversion to mesoporphyrin.

Band 2. This band in chloroform solution was evaporated to dryness in portions. One of these was dissolved in pyridine and examined in the spectrophotometer. The following maxima were obtained:

$\begin{array}{ccccc}\text { I } & \text { II } & \text { III } & \text { IV } & \text { Sorêt } \\ 648 & 590 & 562 & 519 & 425 \quad \mathrm{~m} \mu\end{array}$

The curve obtained was clearly of the rhodo-type (that is, the optical density of the peaks of absorption decreased in the order III, IV, II and I). This fact, together with the positions of the maxima of absorption, strongly suggested chlorocruoroporphyrin. The oxime was prepared (at Sheffield) and a spectrophotometric examination in pyridine showed a characteristic shift of the absorption maxima towards the blue:

$\begin{array}{cccl}\text { I } & \text { II } & \text { III } & \text { IV } \\ 638 & 580 & 548 & 507 \quad \mathrm{~m} \mu\end{array}$

This is good evidence for the presence of a formyl (- $\mathrm{CHO})$ group. Authentic chlorocruoroporphyrin, prepared from Myxicola-Sabella blood, gave an oxime with maxima at:

$\begin{array}{ccccc}\text { I } & \text { II } & \text { III } & \text { IV } & \\ 639 & 579 & 543 & 507 & \mathrm{~m} \mu\end{array}$


To determine the presence of vinyl groups, the porphyrin was treated with diazo-acetic ester followed by hydroxylamine. This produced a shift to the blue, but the rhodo-type spectrum was retained. The maxima in pyridine were:

$\begin{array}{ccccc}\text { I } & \text { II } & \text { III } & \text { IV } & \\ 645 & 586 & 557 & 516 & \mathrm{~m} \mu\end{array}$

This is consistent with the presence of one vinyl group, and is confirmatory evidence for the porphyrin being chlorocruoroporphyrin.

As an additional check on the identity of the main porphyrin of Luidia, the following experiments were carried out.

Fresh Luidia tissue was extracted by the ether : acetic acid procedure, and after the usual purification, the porphyrins were esterified by standing dissolved in methanol: $\mathrm{HCl}$ for $48 \mathrm{~h}$ at $0^{\circ} \mathrm{C}$. The esters, after purification, were dissolved in dry chloroform and separated by chromatography on a column of alumina packed in a mixture of equal parts of chloroform and ether (Lemberg \& Parker, I952). The band of protoporphyrin dimethyl ester passed rapidly down the column well in advance of the main band of chlorocruoroporphyrin ester, and was discarded.

The chlorocruoroporphyrin band was collected, filtered, and the solvent removed in vacuo without heat. The residue was dissolved in glacial acetic acid saturated with sodium chloride and the chlorocruorohaematin prepared, the iron being introduced by the method of Paul (I950).

The chlorocruorohaematin was converted into the haemochromogen by the method of Warburg, Negelein \& Haas (1930), viz.: the haematin was dissolved in aqueous pyridine (pyridine I $\mathrm{ml}$. : water $3 \mathrm{ml}$.) and one-tenth of the volume of hydrazine hydrochloride solution added (hydrazine hydrochloride $0.7 \mathrm{~g}$ in $5 \mathrm{ml}$. water $+5 \mathrm{ml}$. of $2 \mathrm{~N}-\mathrm{NaOH}$ ). The haemochromogen gave the following bands in the Hartridge Reversion Spectroscope:

$$
\begin{array}{ccc}
\text { I } & \text { II } & \text { Intensity } \\
584.4 & 545.9 \mathrm{~m} \mu & \text { I }>\text { II }
\end{array}
$$

This result agrees well with that obtained for chlorocruorohaemochromogen by Lemberg \& Falk (I95I):

$\begin{array}{ccc}\text { I } & \text { II } & \text { Intensity } \\ 583 \cdot \mathrm{I} & 545 \cdot \mathrm{I} \mathrm{m} \mu & \text { not given }\end{array}$

The haemochromogen from the 'haem $a$ ' obtained from ox-hearts by Rawlinson \& Hale (I949) gave only one band in the visible spectrum at $587 \mathrm{~m} \mu$ (Lemberg \& Falk, I95I ; Falk \& Rimington, I952; Rimington, Hale, Rawlinson, Lemberg \& Falk, I949).

These experiments distinguish clearly between the main porphyrin obtained from Luidia and the porphyrin $a$ from haem $a$ of heart muscle. In addition, the spectrum of the Luidia porphyrin-chlorocruoroporphyrin-is of the rhodo-type-intensities III, IV, II, I-whereas that of the porphyrin $a$ 
is of the oxorhodo-type-intensities III, II, IV, I. The porphyrin in Luidia occurs free, and not as a haem.

\section{The Porphyrins of Astropecten irregularis}

The integuments of fifty specimens of Astropecten irregularis were carefully stripped off and extracted with methanol/sulphuric acid overnight in the usual way. The pigments were taken into chloroform and the extract washed and evaporated by the conventional technique. The evaporated chloroform extract was redissolved in dry chloroform and chromatographed on a column of magnesia grade III (Nicholas, I95I), developing with chloroform with increasing concentrations of methanol, as for Luidia. The same type of chromatogram was obtained, and the two red fluorescent bands were shown to be protoporphyrin III type 9 and chlorocruoroporphyrin in the same way and by the same tests as were applied to the porphyrins of $L$. ciliaris. Astropecten, however, appeared to have much less porphyrin (and particularly protoporphyrin) in the integument than Luidia, although no quantitative investigation was carried out at this stage.

\section{Discussion}

This survey of a number of marine invertebrates from eight phyla shows that porphyrins are present in eight species for certain (with one doubtful species Tethya aurantium), and that these eight species belong to only three phylaAnnelida, Mollusca and Echinodermata. Porphyrins were not found in any of the coelenterates, crustaceans or tunicates examined, although MacMunn (I887) found haematoporphyrin in the madreporarian corals Flabellum variabile and Fungia symmetrica.

The finding of uroporphyrin in the upper soft integument of Duvaucelia plebeia (better known as Tritonia) and Aplysia punctata is of considerable interest in view of the presence of this pigment in some mollusc shells (Nicholas \& Comfort, 1949). MacMunn (I887) found 'haematoporphyrin' in the black slug Arion empiricorum (a synonym introduced by Férussac, Férussac \& Deshayes, I8I9-5I, to cover the numerous colour and pattern varieties of the slug more generally known as $A$. ater). Thus the only molluscs which have been shown definitely to contain a porphyrin in their soft parts are either species without shells (Duvaucelia and Arion) or species with uncalcified shells (Aplysia), whereas uroporphyrin, with traces of coproporphyrin, occurs in several of the shells of shell-bearing species. This suggests that in molluscs the porphyrin is normally laid down in the shell (an integumentary product), or failing that in the uncalcified integument. The former would be in keeping with the deposition of uroporphyrin I in the bones and teeth in congenital porphyria, and in the bones of the Pennsylvanian foxsquirrel Sciurus niger (Turner, 1937). Turner connected the formation of the 
uroporphyrin I with the megaloblasts of the bone marrow, and postulated that in Sciurus there exists a unique persistence into the adult span of the normal method of foetal haemoglobin synthesis.

Protoporphyrin III type 9 occurs in the shells of the eggs of the hen and of a plover (Fischer \& Kögl, I924). Borst \& Königsdorfer (1929), Fikentscher (I932), Fraenkel (1924) and Hammer (1930) found that small amounts of porphyrin occur in the bones of the human foetus, as well as in those of newborn babies and other newborn mammals, mainly in the centres of ossification. It is also interesting to recall the experiments of these workers with growing animals, in which injected uroporphyrin I and haematoporphyrin III type 9 were quickly deposited, the latter being required in large amounts before deposition takes place. Bingel (1937) showed that uroporphyrin III was also deposited in bones and teeth. Coproporphyrin I, mesoporphyrin III type 9 and protoporphyrin III type 9 appear to have a slight tendency to deposit in this way. The bones of the foetus do not become impregnated with porphyrins injected into the mother, according to Borst \& Königsdorfer (1929) and others, but Kench, Langley \& Wilkinson (1953) have shown that porphyrins are transmitted through the placenta but are rapidly excreted. This is surprising in view of the known affinity of one porphyrin at leasthaematoporphyrin-for actively growing tissues (Figge, Weiland \& Manganiello, 1948; Kennedy, 1952). The deposition of porphyrins in the asteroids is perhaps somewhat similar, although it is difficult to demonstrate whether the porphyrins are present in the spicules or not, owing to the difficulty of separating the spicules from the integument without destroying any porphyrin they might contain. The presence of free chlorocruoroporphyrin in Luidia ciliaris and also in Astropecten irregularis is of great interest, since this porphyrin has hitherto only been found to occur naturally in the form of its haemoglobin, chlorocruorin, in the blood of sabellid worms (Fox, I926, 1949). Lemberg \& Legge (1949) have suggested that 'since this pigment is found only in a small group of worms which live in the same type of environment as do others containing erythrocruorin with protohaem IX as prosthetic group, the peculiarity does not appear to be of adaptive importance, and may be an evolutionary relic'.

In the three species of echinoderms shown to contain porphyrins, Asterias rubens has only protoporphyrin (Kennedy \& Vevers, 1953 $b$ ) which has two vinyl groups, while Luidia ciliaris and Astropecten irregularis have chlorocruoroporphyrin, which has one vinyl and one formyl group. Luidia ciliaris and Astropecten irregularis also have protoporphyrin in the integument. Warburg (1932) considered that the presence of a carbonyl $(=\mathrm{CO})$ group in a side chain (which later becomes a vinyl group) is a primitive characteristic. The occurrence of chlorocruoroporphyrin in Luidia and Astropecten, both phanerozonian asteroids, may therefore be regarded as an additional argument for classifying the Phanerozonia as less specialized than the Forcipulata such 
as Asterias rubens (Grassé, I948, p. 237). Apart from this, however, it would appear that the distribution of integumentary porphyrins in starfishes is not only random in relation to their taxonomic position but also in relation to their ecology and mode of life. Thus the presence of protoporphyrin in A. rubens and its absence in Marthasterias glacialis is surprising, for not only are these two starfishes classified in the same family (Asteriidae), but their larvae are almost identical in form and scarcely distinguishable (Mortensen, I927), and the adults feed in the same way on the same type of food. In areas where their geographical ranges overlap, as they do off Plymouth, these two species may, in fact, be said to occupy the same ecological niche.

In the polychaetes the porphyrin is probably present in the viscera, but this is less certain as it is often difficult to separate integument from viscera in sufficient quantity for analysis. In Chaetopterus, in which the digestive tract was separated from the rest of the animal for extraction, the porphyrins certainly came from the viscera.

\section{SUMMARY}

A survey of forty-eight species of British marine invertebrates has shown that porphyrins which have not previously been described in these animals are present in three representatives of the Annelida, two of the Mollusca and two of the Echinodermata. The occurrence of protoporphyrin in Asterias rubens was confirmed in a previous paper (Kennedy \& Vevers, I953b). A redfluorescent extract was obtained from the sponge Tethya aurantium, but it contained too little material for further investigation. No trace of a porphyrin was found in the coelenterates, crustaceans and tunicates examined, although Moseley found 'polyperythrin' (which MacMunn later identified with the 'haematoporphyrin' of Asterias and Arion) in Flabellum and Fungia.

Chlorocruoroporphyrin was found free in the starfishes Luidia and Astropecten. Uroporphyrin was extracted from the soft dorsal integument of Duvaucelia (= Tritonia) plebeia, and from the integument of Aplysia punctata, observations of interest in view of the widespread occurrence of uroporphyrin in mollusc shells.

Coproporphyrin III was characterized from extracts of the viscera of Myxicola infundibulum, Nereis diversicolor and Chaetopterus variopedatus. Evidence of the occurrence of a penta-carboxylic porphyrin was obtained from paper chromatography of the extract from the gut of Chaetopterus.

These findings are discussed in comparison with the distribution of porphyrins in birds and mammals. 


\section{REFERENCES}

Bingel, A., 1937. Die Bedeutung der Porphyrine für die Pathogenese gewisser neurologischer Krankheitsbilder. Z. ges. Neurol. Psychiat., Bd. I58, pp. 79-83.

BORST, M. \& KöNIGSDORFER, H., I929. Untersuchungen über Porphyrie, mit besonderer Berücksichtigung der porphyria congenita. 279 pp. Leipzig.

Chu, J. C., Green, A. A. \& ChU, E. J., I95I. Microchromatography of porphyrin esters. F. biol. Chem., Vol. 190, pp. 643-6.

FALK, J. E. \& Benson, A., I 953 . Separation of uroporphyrin esters I and III by paper chromatography. Biochem. F., Vol. 55, pp. IoI-4.

FALK, J. E. \& Rimington, C., I952. Attempted isolation of haem $a$ and porphyrin $a$ from heart muscle. Biochem. F., Vol. 5I, pp. 36-45.

Férussac, J. B. L. d'A., Baron de, Férussac, A. E. J. P. J. F. d'A. de \& Deshayes, G. P., I8I9-5I. Histoire naturelle des mollusques terrestres et fluviatiles. 4 Tomes and Atlas. Paris.

Figge, F. H. J., Weiland, G. S. \& Manganiello, L. O. J., I948. Cancer detection and therapy. Affinity of neoplastic, embryonic and traumatized tissues, for porphyrins and metalloporphyrins. Proc. Soc. exp. Biol., N.Y., Vol. 68, pp. 640-I.

FikentsCheR, R., I932. Quantitative Porphyrin-Bestimmung durch Lumineszenzintensitätsmessung mit dem Stufenphotometer. Biochem. Z., Bd. 249, pp. 257-69.

FISCHER, H. \& KöGL, F., I924. Zur Kenntnis der natürlichen Porphyrine. IX. Über Ooporphyrin aus Kiebitzeierschalen und seine Beziehungen zum Blutfarbstoff. Hoppe-Seyl. Z., Bd. I38, pp. 262-75.

FraENKel, E., I924. Experimentelles über Hämatoporphyrie. Virchows Arch., Bd. 248 , pp. $125-136$.

Fox, H. Munro, I926. Chlorocruorin: a pigment allied to haemoglobin. Proc. roy. Soc., B, Vol. 99, pp. I99-220.

- 1949. On chlorocruorin and haemoglobin. Proc. roy. Soc., B, Vol. 136, pp. 378-88.

Grassé, P., I948. [Ed.] Traité sur la Zoologie, T. Ir. p. I077. Paris.

HAMmER, H., I930. Zur experimentellen Hämatoporphyrose der Knochen. Virchows Arch., Bd. 277, pp. 159-73.

Kench, J. E., Langley, F. A. \& Wilkinson, J. F., I953. Biochemical and pathological studies of congenital porphyria. Quart. F. Med., Vol. 22, pp. 285-94.

Kennedy, G. Y., I952. British Empire Cancer Campaign, XIIIth Annual Report, p. 201.

— 1953a. A new apparatus for column chromatography. Scand. F. clin. Lab. Invest., Vol. 5, pp. $20 \mathrm{I}-2$.

- I953b. Partition paper chromatography of the porphyrins. A new apparatus. Scand. F. clin. Lab. Invest., Vol. 5, pp. 28I-4.

Kennedy, G. Y. \& Vevers, H. G., I953a. Protoporphyrin in the integument of Asterias rubens. Nature, Lond., Vol. I7 I, p. 8I.

- 1953b. The biology of Asterias rubens L. V. A porphyrin pigment in the integument. F. Mar. biol. Ass. U.K., Vol. 32, pp. 235-47.

LEMBERG, R. \& FALK, J. E., I95I. Comparison of haem $a$ the dichroic haem of heart muscle and of porphyrin $a$ with compounds of known structure. Biochem. F., Vol. 49, pp. 674-83.

Lemberg, R. \& Legge, J. W., I949. Haematin Compounds and Bile Pigments. New York. 
Lemberg, R. \& Parker, J., I952. Porphyrins with formyl groups. II. Preparation of chlorocruoroporphyrin diformyldeuteroporphyrin. Aust. F. exp. Biol. med. Sci., Vol. 30, pp. 163-70.

MACMUNN, C. A., I887. On the presence of haematoporphyrin in the integument of certain invertebrates. F. Physiol., Vol. 7, pp. 240-52.

Mortensen, T., 1927. Echinoderms of the British Isles. 47I pp. Oxford University Press.

Nicholas, R. E. H., I95I. Chromatographic methods for the separation and identification of porphyrins. Biochem. F., Vol. 48, pp. 309-13.

Nicholas, R. E. H. \& COMForT, A., I949. Acid soluble pigments of molluscan shells. 4. Identification of shell porphyrins with particular reference to conchoporphyrin. Biochem. F., Vol. 45, pp. 208-Io.

Nicholas, R. E. H. \& Rimington, C., I949. Qualitative analysis of the porphyrins by partition chromatography. Scand. F. clin. Lab. Invest., Vol. I, pp. I2-I8.

PAUL, K-G., I950. The conversion of ferri-porphyrins (hemins) to their corresponding porphyrins by means of pyruvic acid. Acta chem. Scand., Vol. 4, pp. I22I-32.

Rawlinson, W. A. \& Hale, J. H., 1949. Prosthetic groups of the cytochromes present in Corynebacterium diphtheriae with especial reference to cytochrome $a$. Biochem. F., Vol. 45, pp. 247-55.

Rimington, C., Hale, J. H., Rawlinson, W. A., Lemberg, R. \& Falk, J. E., I949. Ist Int. Congr. Biochem. (Abstr.), p. 379.

TURNER, W. J., I937. Studies on porphyria. I. Observations on the fox-squirrel, Sciurus niger. F. biol. Chem., Vol. I 18, pp. 519-30.

WARBURG, O., I932. Das sauerstoffübertragende Ferment der Atmung. Z, angew. Chem., Bd. 45, pp. I-6.

Warburg, O., Negelein, E. \& HaAs, E., I930. Spirographishämin. Biochem. Z., Vol. 227, pp. I7I-83.

WILlStÄTtER, R. \& STOLL, A., I9I3. Untersuchungen über Chlorophyll. 424 pp. Berlin. 